\title{
Ó di gbéré, ó di kése, Adébayọ Fálétí
}

\author{
Lere Adeyemi \\ Department of Linguistics and Nigerian Languages \\ University of Ilorin \\ Nigeria \\ adeyemiolalere@yahoo.com
}

Bínú bá ń bífá,

Ọmọ aráyé á fewúrẹe dúdú bọfá;

Bínú ọpẹ̣lẹ ò dùn,

Ọmọ aráyé a f'àgùtàn bọ̀lọjọ̀ șètùtù;

Orógbó pẹ̀lóbì lẹbọ Șàngó

Bí Lakáayé ń bínú,

Aráyé a fún un lájá jẹ.

Ikú kọ̀, ikú kò gbẹbọ.

Sé bíkú bá jẹja láyé ijộsí,

Owọ́ ikú a máa gbọ̀n iróró iróró,

Bíkú bá jeku nígbà ìwáșẹ̀,

Esẹ rẹ̀ a máa gbọ̀n irì̀ì irìrì,

Bíkú bá jẹyin ẹlẹ́butẹ, ara ikú a máa já ibùtẹ ibùtẹ,

Ikú àsìkò yî́ bàjẹ kò gbẹbọ kò gbètùtù,

İkà nikú, ikú kò màgbà bẹeẹ ni kò mọmọdé,

Bílé oyin bá kan gbínrín gbínrín,

Bẹee wádìi rẹ̀ wò, ișé ikú ni,

Bọ́dẹdẹ adò bá sì dibi ikorò,

Ikú ló fa sábàbí ẹ.

Ikú pagbe bí ẹni tí ò dáró,

Ikú pàlùkò bí ẹni tí ò kosùn,

Ikú pa lékèélékèé bí ẹni tí ò kẹfun,

Ikú ộhún ló pa Adébáyọ ọmọ Fálétí,

Bí ẹni pé Ifá ò létí, 
Ikú pàkọ̀kọ́ ó fomi akọ̀kọ́ șòfò!

Lọjộ mo gbọ́kú ọmọ Fálétí,

Tí mo jí láfẹ̀mọ́júmọ́ kóri ìdájí ó tó tó dá,

Mo bojú wapá mi ọ̣tún, gbogbo ìú dákẹe șírișíri,

Gbogbo igbó pa kánrin kése,

Ọmọdé ilé, wọn ò lè sọkún ọmú,

Enní jókòó, wọn ò lè dìde,

Ẹní tó nàró, kò lè bẹ̀rẹ̀,

Kowéè kan wá ǹ ké líle líle,

Kò sí ẹ̀ọ̀ pẹsẹe lóhùn ẹyẹ awo,

Àșé ọmọ Ọyỳnyìn a-tàn-bí-wúrà,

Ọmọ Fálétí ló lọ gbèkuru jẹ lọ́wọ́ ẹbọra,

Așe ẹni mo rò pé kò lè kú lógún ọdún síbí,

Aṣe agbáșàga ti mo rò pé kò lè papòdà lọgbọ̀n oṣù,

Pé yóò sìn wá dẹesẹ omi,

Lomi ikú ti wọ́ lọ sálákeji,

İràwọ̀ àgbà ti jáludò, kò leè tàn mọ́,

Ò tẹ̀rókò ìmọ̀ fidà rọ̀, ó ti lọ,

Òkéké! A-rẹnu-ké-ọràn-bí-ộbẹ, ó ti lọ,

Àtàtà ònkọ̀wé, afínjú akéwì tí ń fewì sọ̀tàn,

Ọmọ İdọ́dẹ, Pàràkòyí ọmọ Ọyọ́ Aláàfin, ó ti lọ

Bí Adébáyọ̀ Fáléti ti pẹ́ tó láyé,

Tó dàgbà darúgbó kàngẹ́kàngẹe,

Sibẹ̀, lọjộ ti baba relé,

Ajá kọ̀, ajá ò gbeegun,

Adiyẹ rọ́kà, wọn ò yọ șẹẹ̣ẹ

Gbogbo ọmọ Yọrùbá ló ń șèdárò akọni

Àwọn òșèré ń șe ìdárò akọni,

Egbẹ́ akéwì, ẹgbẹ́ sọ̀rọ̀sọ̀rọ̀ ń ședárò akọni,

Egbẹ́ onímọ̀ Yorùbá ń șèdárò ẹni rere

Gbogbo ọba Yorùbá ló ń mìrùkẹ̀rẹ pẹ̀lú ẹdùn ọkàn

Nígbà tó wà láyé, bí baba tì ǹ gbọ́ tẹrú

Ní baba ǹ gbọ́ tọmọ,

Ó gbọ́ ti Tápà léǹpe, ó gbọ́ tabokí

Ó gbọ́ ti Yánmírín, ó fi eré fî̀mù gbọ́ tiwọn lájìndò Gúsù

Òkìtì gbogbo kọ́ ní hu olú ọgán

Gbogbo ọmọ olóyè kọ ní róyè ọba jẹ,

Onífilà àgọgọ̀ joyè ìmọ̀, ó fi șe gbogbo ayé lóore

Àwọn eré, àwọn orin àti ìtàn-àròsọ rẹ̀

Ló jẹe ajómọ-lẹ́sệ-bí-ìpìn!

Gbogbo àrokò rè nínú eré fí̀mù À fọ̀njá 
Kí Yorùbá ó lè dọ̀kan șoṣo

Kí ìran Odùduwà, tó jọ́mọ alátẹ ilệkẹ,

Kó má dọmọ alátẹ ọ̀rúnlá tí ń bá àbókí gbẹ kànga

Kó tó șe rere nílẹ̀ Nàijá.

Enin tó magbe, kò bá ní dárò aró,

Ẹní tó màlùkò kò bá ní dàrò osùn

Enní tó mọ lélèélékèé kò bá ni dárò ẹfun

Ẹní tò bá mọyì àgbà,

Kó bá ní dárò akọni.

Atóófọjọ́mọ, Alágbẹ̀dẹ èdè

Àgbà òpìtàn, arótàn bí ọ̀pẹlẹ̣

Erin gùnkè àlộ, ẹran lọ Àkẹẹẹ!

Ògìdán ò pè méjì níjù

Háà! Òkéré gorí ìrókò

Ojú ọdẹ dá!

Ọmọ Yorùbá ẹ kú ìdárò akọni.

Ó tọ́, ó sì yẹ kí ń sọ gínńgín lórí iṣé tí baba șe

Kí baba ó tó dágbére fáyé

Bí a bá pérí akọni, à fidà lalẹ

Bí ò bá sí iṣu kí la ó gún níyán?

Bí ò bá sí èlùbọ́ kí la ó rò lọ́kà?

Bí ò bá ságbàdo, ẹệrùn,

Kí la ó rò lẹ́kọ yangan

Òpẹlọpẹ, ọmọ Fálétí afitànkọ́mọ-níwà-Oòdáyé

Kínńkín ní à bà mọ nítàn ìṣẹdálè Ọyọ́,

Bí kò sí ere-onítàn, ìàn-àròsọ àti ewì tó fi pàrokò

İtàn ìsẹ̣dálẹ̀ Ọyọ́ ỉbá șàjèjì sí ìran òde òní

Oppẹ́lọpẹ́ òpitàn, ònkọ̀tàn, aròtàn tó morírun Òyọ́,

Ó mọ̀tàn Ifẹ̀, ó tún mọ tèkìtì òkè

Ọjọ́ tọ́mọdé bá kọán àná,

Àwọn àgbà a fitàn balẹ̀,

Ọjọ́ ò tò jọ́jọ́, ọjọ́ ò tọjọ̣

Tógun ajunilọ dó sílẹ Kòkànmí

İmúnisìn ilé, ìmúnisìn oko,

Ogun ajunilọ dó sílẹ Oòduà,

Ọmọdé ilé kò rójú,

Àwọn àgbà kùjọ́kùjọ́ ibẹ kò ràyè,

Wọn gbèdè lệnu elédè wọ́n gbàrùkẹ̀rẹ̀ lówọ́ ọba wọn,

Babaláwo pe fá títí, ifá ò gbọ́, 
Onísègùn pọ̀pẹlè títí, ọ̀ pẹ̀lẹ ò gbẹbẹ̀,

Onígbàgbọ́ pẹ́ nílé olúwà bí kộbọ̀ àkộdé,

Àwọn mùsùlùmí pẹ lọộdè Ànábì bí tọ̀yọ́bọ̀,

Gbogbo akọni ló tí dẹrú alágbára

Àfòpìtàn tó gbédè bí òfé ló lérò tọ yàtọ

Ọlộgbộn-inú- Òyộ kéré jọ nílùú Òyọ́

O șeré Sùurù àti ọgbọ́n pé kí kálukú ó fọgbọ́n șe

Eré yìi gbayì, ó gbẹ̀yẹ, ó tún fálágbára ní sùúrù.

İwé ìàn-àròsọ Ọmọ Olókùn Ẹsin ló tú àșírí àwọn alágbára

Kó tó di pé àwọn alágbára ilé àti toko fi sinmẹ̣dọ

Alágbára lọ, șúgbón kò bá wọn wá kì í ba wọn lọ

Àșà àtiṣe Yorùbá tún rẹesẹ walẹ.

Lẹ́yìn òmìnira ń kọ́? ọmọ Fálétí șe bẹbẹ

Ó kọ̀wé, ó kọ̀tàn, ó tun kọrin tó lárinrin fómìnira

Ó kộwé kan ó pè é ní Ogun Àwítẹelẹ

Ogun àwítẹlẹ̀ tí kì í parọ tó bá gbọ́n,

Ogun olè, ogun ajộmọgbé bẹ̀rẹ ní ràbájìgan

Enní ǹ rogun ojúgbo,

Kó máà jorógbó onígbó

Ení bá togun dé ní wọn ǹ kí kú oríire

Ẹni tàjò dé ní wọn ǹ kí 'ẹ kí ewu ọ̀nà'

Fálétí pàrokò títí, ogun àwítẹlẹ kọ kò lọ,

Agbódórogun kò sì padà bọ̀.

Bí șe ǹ kọrin, ló ǹ kéwì ló tún ń kọ̀wé,

Lệyìn òmìnira Nàijíría ni ìnira tuntun wọlé dé,

Gbẹgẹdẹ tún gbiná si,

Lòmìnira fimú ẹlẹ́dẹ gùn dọ́gbà,

Làwọn olóṣèlú gbàbọ̀dì,

Àbẹtệlẹ wọ̀lú, ló bá dolórúkọ gídi,

Owó èyyìn wá dọmọ onílẹ lọ́dọ̀ wa,

Ló wa dolórúkọ ńlá,

Òun náà ní wọn ǹ pé ní rìbá,

Sọwọ́kúdúrú wá ǹ șebí láàárín wa,

Fálétí ké ké ké,

Ó yán yán yán,

Kí ìwà olè àti rìbá ó le dẹ́kun lááárín ìlú,

Ó dẹgbé eléré Alébíoṣù sílẹ,

Ó ǹ șere Șawoṣọ̀gbẹ̀rì,

Ó șeré Fẹrẹ bí ẹkùn lórí amóhùnmáwòrán 
Bóyá, aráyé a șíwộ iṣẹ íbí șiṣe

Àwọn aláágànná ẹdá

Àwọn asínwín ayé gbogbo kọ̀ wọn ò gbọ́

Wộn ń purọ́ wọ́n ń tan aráyé jẹ kiri

Wọn lówó borí ọmọ ni wọ́n ń hùwà ẹranko kiri,

Gbogbo wọn ló ń kówó ilú jẹ bí ẹni jẹșu,

Fálétí kéwì lórí rédío ló tún dọ̀ràn.

Sé tibitire ló ǹ rìn pọ̀ láyé ọmọ ènìyàn,

Kì í dùn, kó má kan,

Kì í sì kan, kó má dùn,

Bí ènìyàn ò fẹnu kan ìbó wò,

Kò ní mọyì oyin lẹnu,

İṣèdálẹ ayé ni,

Lọmọ aráyé ń fọmọ wọn șẹsó,

Ènìyàn gidi ń șe bí wèrè lọjà ọba,

Aráyé rò pé wèrè gidi ni,

Ni Fálétí fi kọ Nwọn rò pé Were ni,

Wèrè gidi kọ wérewère ni o jàre.

Nigbà tó bùșe gàdà, tó bùșe gèdé,

Làwọn șọ́jà tún gbòde,

Fálétí tún gbéré İjà Orogún dórí àtẹ,

Ní șójà àtolóṣèlú ǹ yíra wọn sébè,

Wọn ǹ yira wọn sáporo oko,

Șójà dé, òbúkọ dé, òórùn dé, ijàṅbá wọ̀lú,

Olórí ọlóșà wá ǹ sọ ìgboro,

Bẹẹ ní ijà ẹlẹ́yàmẹyà, ijà ẹ̣̣ìn șe bẹeẹ tó wòlú,

Ó wọ̀lú wẹ́rẹ́ ni ẹ̀sìn ń dààmú ẹeẹ́sìn,

İdààmú páádì Míǹáǹlù ló fèyí han.

Gbogbo ìdààmú ilú tó farahàn ninú ìú,

Lọmọ Fálétí wộnà àbáyọ fún nínú ìwé rẹ̀,

E ka Àșà Agúnbẹ nínú 'Awòrérìn,

E ka Àgbàlagbà já lórí igi,

Șebí káyé ó lè dára fún wa ni.

Adébáyọ Fálétí șe bẹbẹ fun ìran ènìyàn,

Nígbà ti ìlú fệrẹẹ fọ́ mọ́ olórí ilẹ yìi kan lórí,

Ògàgun náà gbóná ó ju iná lọ,

Șé iná kan ì i gbóná, kó gbóná tewétewé,

Yèèsì kan ò sì gbóná, kó gbóná tegbọ̀tegbò, 
Ataare kì í gbóná, kó gbóná tèèpo tèèpo,

İwà èèpè tó mulẹ níkùn alágbára tí à ń wí,

Ó pọ ju iwa rere lọ,

İwà ìkà ló gbé wọ̀ bí ẹ̀ù̀,

Káráyé ó lè rộgbộn kọ́,

Ní Fálétí fí gbéré Bașọ̀run Gáà tó ti kọ lọjộ pipe,

Jáde sórí fiìmù àgbéléwò, bóyá àyípadà yóò dé báwùjọ wa,

Ẹni tó bá ka ewì baba nínú Ewì İwòyí,

Yóò mọ pé ẹran ki sẹ́sẹ ràgó.

Ọlọgbộn ilé Òyộ, ọmọ Fálétí ti lọbi àgbà rè,

Ike dá, owó iké gbé,

Sèsé là, ó là dànù,

Ọpáláńbá ọtí èèbó fọ́, onígbǹsọ kò rí i sọ,

Odó iyán dodó ẹlú, baba wa ti lọ.

Bí o bá délé, o kílé, bí o dọnnà, $o$ kérò ọ̀nà

E bá mi kí baba mi tó ti ń bárá ọ̀run jẹ lộjọ́ pípé

Ọmọ ọlọ́lá joyè méjì pọ̀,

Ọmọ ọ̀yẹ kệkẹ́ oníbàrá òjé,

E bá mi kí ìyá mi, Aríbakẹ İbídọjà ọmọ akọléiyán,

Onísùúrù ló lè fún wàrà kìnnìún,

E bá mi kí àwọn àgbà ọjẹ̀ bí Olóyè Oludare Olájubù,

E jísẹ́ mi fún baba Afọlábi Olabimtan, Orílawẹ Àdìgún,

Orí la wẹ̀ a ò wẹse kànìnkànìn la wẹ̀, a ò wẹjìnrìn,

E bá mi kí Páàdì Ilésanmí, tó ti débi ìsinmi,

E má gbàgbé àwọn akọni ọmọ Yorùbá yòókù pátá,

Tí wọ́n ń bẹ lájùlé ọ̀run,

Ọmọ Fálétí, ó di gbéré,

Ó di kése, ó dàrìnàkò, ó dojú àlá,

Ó tún dọjọ́ mìrràn ká t'o túnra rí,

İpàdé dọjọ́ àjínde lẹ́sẹ Olùgbàlà! 


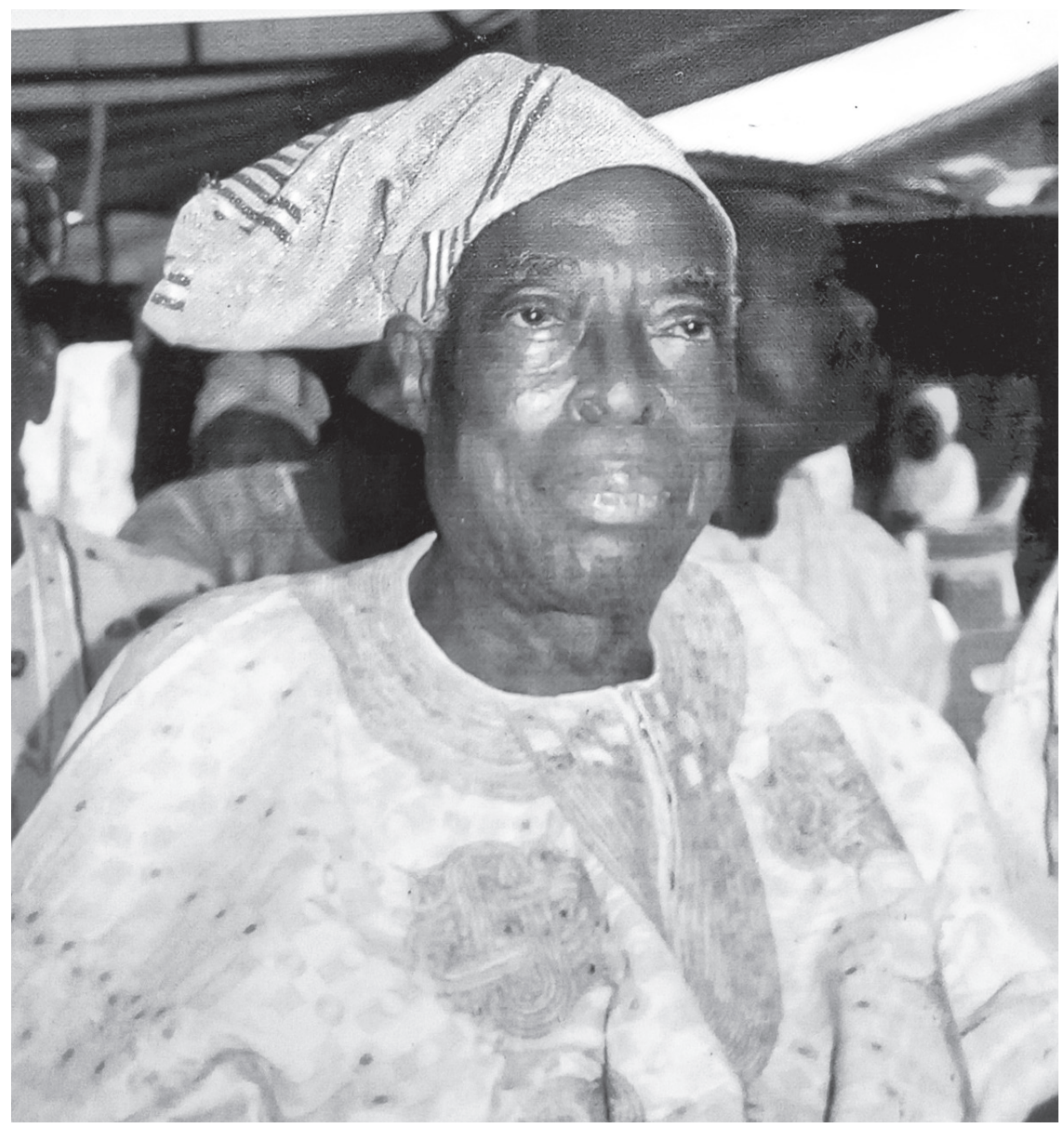

